\title{
Nutritive value of full-fat dehulled sunflower seeds in diets for broiler chickens
}

\author{
E. Sosa-Montes ${ }^{2}$, U. Martínez-Martínez ${ }^{1}$, A. Pro-Martínez ${ }^{1 \#}$, F. González-Cerón ${ }^{2}$, J. Gallegos- \\ Sánchez ${ }^{1} \&$ L.T. Rodríguez-Ortega ${ }^{3}$ \\ ${ }^{1}$ Postgraduate College, Campus Montecillo, Texcoco, State of Mexico, 56230, Mexico \\ ${ }^{2}$ Chapingo Autonomous University, Chapingo, State of Mexico, 56230, Mexico \\ ${ }^{3}$ Universidad Politécnica de Francisco I. Madero, Tepatepec, State of Hidalgo, 42660, Mexico
}

(Received 2 December 2020; Accepted 14 April 2021; Published 30 August 2021)

\author{
Copyright resides with the authors in terms of the Creative Commons Attribution 4.0 South African Licence. \\ See: http://creativecommons.org/licenses/by/4.0/za \\ Condition of use: The user may copy, distribute, transmit and adapt the work, but must recognise the authors and the South African \\ Journal of Animal Science.
}

\begin{abstract}
The goal of this research was to evaluate the nutritive value of full-fat de-hulled sunflower seeds (DHSS) in feeding broiler chickens. Three experiments were conducted. Experiment 1 determined the proximal analysis of DHSS, the essential amino acid content, and apparent metabolizable energy (AME). In experiment 2, two diets were formulated, namely a control and a diet containing 10\% DHSS. Apparent ileal digestibility (AID) of dry matter (DM), crude protein (CP), and ether extract (EE) were calculated. In experiment 3 , the performances of broilers fed the two diets were evaluated in terms of the relative weights of digestive system organs, breast meat colour, growth and feed consumption. Full-fat de-hulled sunflower seeds were characterized as having $507.9 \mathrm{~g} / \mathrm{kg} \mathrm{EE}, 282.1 \mathrm{~g} / \mathrm{kg} \mathrm{CP}, 21.02 \mathrm{MJ} / \mathrm{kg} \mathrm{AME}$ and $9.3 \mathrm{~g} / 16 \mathrm{~g} \mathrm{~N}$ arginine. Apparent ileal digestibility of DM in the $10 \%$ DHSS diet was $658.0 \mathrm{~g} / \mathrm{kg}$, similar to that of the control diet $(643.0 \mathrm{~g} / \mathrm{kg})$. Partial substitution of DHSS for soybean meal (SBM) did not affect the relative weight of digestive system organs, except for the liver. The relative weights of the liver were $17.90 \mathrm{~g} / \mathrm{kg}$ bodyweight in birds fed the DHSS diet and $16.37 \mathrm{~g} / \mathrm{kg}$ bodyweight $(P<0.05)$ in the control. The colour of the breast meat was $3.5 \%$ darker and $13.8 \%$ less yellow for DHSS birds compared with the control. Growth and feed consumption were unaffected by the dietary treatments. Therefore, $10 \%$ DHSS can partially replace SBM in broiler finisher diets.
\end{abstract}

Keywords: ileal digestibility, meat colour, metabolizable energy, organ weight

\#Corresponding author: aproma@colpos.mx

\section{Introduction}

Rising prices for ingredients of conventional broiler diets made it necessary to search for alternatives that were nutritive and low in cost (Alagawany et al., 2015). Oilseeds are generally high in their content of oil (energy) and protein (Tsuzuki et al., 2003). Thus, the use of oilseeds in broiler diets has increased.

Sunflower (Helianthus annuus L.) is one of the most important oilseed crops in the world (Konyali, 2017; Kaya, 2020). Sunflower seeds and meal are valuable sources of oil, protein and fibre for humans and animals (Morales-Rosales et al., 2006; Laudadio et al., 2014). However, there is little information about the use of DHSS in broiler finisher diets. Most of the literature refers to sunflower meal (SFM), which is produced when oil has been extracted from the seeds (Alagawany et al., 2015).

The fibre content, digestibility, and bioavailability of nutrients in SFM can vary, depending on whether the hulls are included (Laudadio et al., 2014; Karkelanov et al., 2020) and growth performance can alter because of these differences (Khempaka et al., 2009).

The main objective of the present study was to evaluate the composition and metabolizable energy of DHSS, and the effects of the partial replacement of SBM with DHSS on the digestibility of nutrients, relative weight of digestive system organs, colour of the breast meat, and performance in finisher broiler chickens. In this study, SFM refers to sunflower seed meal after oil extraction without de-hulling, and DHSS to the seed after de-hulling, but without oil extraction. The de-hulling process removes the major fibre components and improves digestibility (Nadeem et al., 2010). Therefore, DHSS is low in fibre, and high in oil and protein in comparison with SFM (Zając et al., 2020). 


\section{Materials and Methods}

The guidelines established by the Animal Welfare Committee of the Postgraduate College (Norma Oficial Mexicana, 2015) were followed in conducting this research.

The experiments were carried out at the animal research facilities of the Postgraduate College at Montecillo Campus and Chapingo Autonomous University, Animal Science Department (Experimental Poultry Farm and Animal Nutrition Laboratory), Texcoco, State of Mexico, Mexico at 19²7'37.8" N, 98 $54^{\prime 2} 29.3^{\prime \prime} \mathrm{W}$, and 2220 m.a.s.l. This region is characterized by a temperate sub-humid climate, with a Köppen climatic classification of $\mathrm{Cb}(\mathrm{w} 0)(\mathrm{w})$ (Huerta-Paniagua et al., 2004).

The sunflower seeds were ground with a hammer mill using a $20 \mathrm{~mm}^{2}$ screen (AZTECA, Mexico). Subsequently, the seeds were sieved successively with 2,3 and $5 \mathrm{~mm}^{2}$ screens and finally the residual hull was removed with a fan (PRO Klima, Speed 45, Croatia) to obtain the DHSS, which was again ground with a hammer mill using a $5 \mathrm{~mm}^{2}$ screen (AZTECA, Mexico).

The DHSS were characterized by proximate analyses (AOAC, 1990) and fibre constituents were partitioned following Van Soest et al. (1991). In addition, the amino acid profile was determined by high performance liquid chromatography (Evonik Industries AG, Essen, Germany).

Two diets (Table 1) were formulated to determine the AME of DHSS by the difference method. The first was based on corn and SBM and the second contained $75 \%$ of this diet plus $25 \%$ DHSS. The diets were randomly assigned to 39-day-old Ross 308 male chickens that weighed $2252.3 \mathrm{~g}$ (SD = 99.5 g). Twelve chickens were adapted to each diet over six days before the feeding trial began. The chickens housed in individual cages that were $30 \mathrm{~cm}$ high $\times 60 \mathrm{~cm}$ long $\times 40 \mathrm{~cm}$ wide. They were fed and provided with water ad libitum with a linear feeder and an automatic water dispenser.

Table 1 Ingredient composition and estimated energies of the corn-soybean meal diet used to determine apparent metabolizable energy

\begin{tabular}{lc}
\hline Ingredients & $\mathrm{g} / \mathrm{kg}$, as fed \\
\hline & \\
Ground corn & 593.6 \\
Soybean meal & 351.8 \\
Soybean oil & 17.8 \\
Dicalcium phosphate & 21.7 \\
Calcium carbonate & 7.8 \\
Sodium chloride & 2.0 \\
Sodium bicarbonate & 2.3 \\
Vitamin and mineral premix ${ }^{1}$ & 3.0 \\
\hline Estimated energy values $^{\text {AME }}$ & $\mathrm{MJ} / \mathrm{kg}$ \\
AME $_{\mathrm{n}}$ & 13.9 \\
\end{tabular}

TPer kilogram of diet, vitamin A: 12,000 IU; vitamin D3: 1,000 IU; vitamin E: $60 \mathrm{IU}$; vitamin K: $5.0 \mathrm{mg}$; vitamin B2: $8.0 \mathrm{mg}$; vitamin B12: $0.03 \mathrm{mg}$; pantothenic acid: $15 \mathrm{mg}$; niacin: $50 \mathrm{mg}$; folic acid: $1.5 \mathrm{mg}$; choline: $300 \mathrm{mg}$; biotin: $0.150 \mathrm{mg}$; thiamine: $3.0 \mathrm{mg}$; Fe: $50.0 \mathrm{mg}$; Zn: $110 \mathrm{mg}$; Mn: $100 \mathrm{mg}$; Cu: $12.0 \mathrm{mg}$; Se: $0.3 \mathrm{mg}$; I: $1.0 \mathrm{mg}$. AME: apparent metabolizable energy, AMEn: apparent metabolizable energy corrected for nitrogen retention

Apparent metabolizable energy was determined with the total excreta collection method. Feed intake and excreta of each bird were measured over four consecutive days, starting at day 45 and finishing when the birds were 49 days old. Care was taken to avoid contamination of the excreta with feathers, scales and feed. The excreta collected from each chicken were mixed, acidified and homogenized, after which a $90 \mathrm{~g}$ pool sample was obtained from two chickens and stored at $-20^{\circ} \mathrm{C}$ for subsequent lyophilization (Labconco Corporation, Kansas City, Missouri, USA). The dry excreta and feed samples were ground in a mortar and stored in airtight plastic containers for further analysis of DM, gross energy (GE)and nitrogen. Gross energy of diets and excreta were determined with an isoperibolic calorimeter (PARR 1266, Parr Instrument Company, 108 Moline, Illinois, USA) and nitrogen with the Kjeldahl method (AOAC, 1990). 

DM):

This formula, following Barzegar et al. (2019), was used to calculate the AME of the diet $\left(\mathrm{AME}_{\mathrm{d}}, \mathrm{MJ} / \mathrm{kg}\right.$

$$
A M E_{d}=\left(\left(F I x G E_{d}\right)-\left(E x G E_{e}\right)\right) / F I
$$

where: $F I=$ feed intake in grams of $D M$,

$E=$ excreta in grams of DM,

$G E_{d}=$ gross energy content of the diet in $\mathrm{MJ} / \mathrm{kg} \mathrm{DM}$, and

$G E_{e}=$ gross energy content of the excreta in $\mathrm{MJ} / \mathrm{kg} \mathrm{DM}$.

This formula determined the AME of the corn-soybean diet control diet $\left(\mathrm{AME}_{\mathrm{c}}\right)$ and that of the diet augmented with $25 \%$ DHSS $\left(\mathrm{AME}_{\mathrm{a}}\right)$. This formula was used to estimate the apparent metabolizable energy of DHSS:

$$
A M E_{\text {dhhs }}=\left(A M E_{a}-0.75\left(A M E_{c}\right)\right) / 0.25
$$

The $A M E_{d h h s}$ value was corrected for nitrogen retention $\left(A M E_{n}\right)$ a factor of $34.4 \mathrm{MJ} / \mathrm{kg}$ of nitrogen retained (Barzegar et al., 2019).

To determine the AID, two diets were formulated according to Aviagen (2017) nutritional recommendations (Table 2). The control diet was based on ground sorghum and SBM, and in the augmented diet $10 \%$ DHSS replaced some of the SBM. Twelve 32-day-old Ross 308 male broiler chickens weighing $1663.6 \mathrm{~g}(\mathrm{SD}=80.0 \mathrm{~g})$ were randomly allocated to each diet. The chickens were distributed individually in cages $(30 \times 60 \times 40 \mathrm{~cm})$ that were equipped with individual feeders and automatic water dispensers. Feed and water were offered ad libitum. The diets were isocaloric and isonitrogenous (Table 3 ) and were provided as mash, for 21 days (32 to 53 days old). They contained $3 \mathrm{~g} / \mathrm{kg}$ titanium dioxide as an indigestible marker. The chickens were acclimatized to the diets for 17 days (32 to 49 days old) and the experimental period took place when the broilers were from 50 to 53 old. On day 53 , all chickens were killed with a stunning knife (Model VS200, Midwest Processing Systems, Minneapolis, Minnesota, USA). The ileum of two chickens was divided in two, and the contents of the distal portions were collected and mixed. Therefore, the experimental unit was the content of two ileums, with six replicates of the control diet and six of the 10\% DHSS diet. All ileum contents were lyophilized (Labconco Corporation, Kansas City, Missouri USA) before analysis. The lyophilized samples of diets and ileal contents were analysed for DM, CP, and EE according to the AOAC (1990), and the titanium dioxide concentration $(\mathrm{g} / 100 \mathrm{~g})$ was determined following Myers et al. (2004). Apparent ileal digestibility of DM, CP and EE was calculated from the concentrations of titanium dioxide in the feed and ileal contents.

Table 2 Ingredients of diets formulated for broilers without and with de-hulled full-fat sunflower seeds

\begin{tabular}{lrc}
\hline Ingredients, $\mathrm{g} / \mathrm{kg}$, as fed & Control diet & 10\% DHSS diet \\
\hline Ground sorghum & 606.1 & 623.9 \\
Soybean meal & 301.2 & 232.0 \\
De-hulled full-fat sunflower seed & 0.0 & 100.0 \\
Soybean oil & 50.0 & 0.0 \\
Dicalcium phosphate & 15.8 & 15.3 \\
Calcium carbonate & 9.3 & 9.7 \\
Vitamin and mineral premix & 3.0 & 3.0 \\
Sodium chloride & 3.0 & 3.0 \\
L-Lysine & 3.7 & 5.4 \\
DL-Methionine & 3.6 & 3.2 \\
L-Threonine & 0.8 & 1.0 \\
Coccidiostat & 0.5 & 0.5
\end{tabular}

\footnotetext{
${ }^{1}$ Per kilogram of diet, vitamin A: 12,000 IU; vitamin D3: 1,000 IU; vitamin E: $60 \mathrm{IU}$; vitamin K: $5.0 \mathrm{mg}$; vitamin B2: $8.0 \mathrm{mg}$; vitamin B12: $0.030 \mathrm{mg}$; pantothenic acid: $15 \mathrm{mg}$; niacin: $50 \mathrm{mg}$; folic acid: $1.5 \mathrm{mg}$; choline: $300 \mathrm{mg}$; biotin: $0.150 \mathrm{mg}$; thiamine: $3.0 \mathrm{mg}$; Fe: $50.0 \mathrm{mg}$; Zn: $110 \mathrm{mg}$; Mn: $100 \mathrm{mg}$; Cu: $12.0 \mathrm{mg}$; Se: $0.3 \mathrm{mg}$; : $1.0 \mathrm{mg}$
} 
Table 3 Nutrient composition of diets formulated for broilers without and with de-hulled full-fat sunflower seeds

\begin{tabular}{lrr}
\hline Determined nutrient values, g/kg DM & Control diet & 10\% DHSS diet \\
\hline Apparent metabolizable energy, MJ/kg & 13.2 & 13.2 \\
Crude protein & 193.6 & 191.0 \\
Calcium & 7.8 & 8.0 \\
Available phosphorus & 3.9 & 3.9 \\
Lysine & 11.5 & 11.5 \\
Methionine & 5.7 & 5.8 \\
Methionine + cysteine & 8.9 & 9.0 \\
Ether extract & 75.6 & 77.6 \\
Crude fibre & 23.9 & 26.4 \\
Neutral detergent fibre & 145.0 & 153.2 \\
Acid detergent fibre & 73.9 & 86.5 \\
Acid detergent lignin & 31.9 & 37.8 \\
Ash & 51.3 & 55.0 \\
\hline
\end{tabular}

DM: dry matter

A feeding trial was conducted with two diets that were similar to those presented in Tables 2 and 3 . Eighty-four 33-day-old Ross 308 mixed-sex chickens were randomly assigned to six replicates of each diet (14 chickens each: seven males and seven females). The chickens weighing $1669.0 \mathrm{~g}$ (SD =84.4 g) were housed in pens of $1.4 \times 1.05 \mathrm{~m}$ with wood shavings as litter, at a density of 9.5 chickens $/ \mathrm{m}^{2}$. The diets were provided as mash, from 33 to 54 days old. Feed and water were provided ad libitum.

Live weight gain (LWG) (g/d), feed intake $(\mathrm{FI})(\mathrm{g} / \mathrm{d})$ and feed conversion ratio $(\mathrm{FCR})$ were recorded weekly, but only the cumulative values from day 33 to 54 were reported.

On day 55, 18 chickens per treatment (three chickens from each replicate) were killed using a stunning knife (Model VS200, Midwest Processing Systems, Minneapolis, Minnesota, USA) according to the Official Mexican Standard (Norma Oficial Mexicana, 2015) to determine the breast colour parameters and the relative size of the digestive system organs. Breast colour was assessed with a Minolta colorimeter (Model CR-400/410, Tokyo, Japan). The readings were taken at equivalent sites on the skin of the breast (Pectoralis major). Three readings were taken and averaged for each chicken. Skin colour was expressed in CIELAB dimensions as three numerical values, brightness $\left(L^{*}\right)$, intensity of red $\left(a^{*}\right)$, and intensity of yellow $\left(b^{*}\right)$.

The lengths of the small intestine and caecum were determined with a measuring tape on the surface of a wet cloth to avoid dehydration and contraction. The fatty tissue and mesentery portions adhered to each section of the digestive system were removed, and the empty $s$ of crop, proventriculus, gizzard, small intestine and caeca were recorded, as well as those of liver, spleen and pancreas. Weight and length data were expressed in relation to live weight ( $\mathrm{g}$ or $\mathrm{cm} / \mathrm{kg}$ live weight).

The data were analysed with analysis of variance using the SAS general linear model procedure (SAS Institute, Inc., Cary, North Carolina, USA) as appropriate for a completely randomized design. Initial live weight was included as a covariate in the statistical analysis of final live weight.

\section{Results and Discussion}

De-hulled full-fat sunflower seeds had a low content of crude fibre (CF) and high contents of CP and EE (Table 4). Therefore, it was a protein-rich ingredient with high AME and AMEn. Thus, similarly to whole soybeans, which contain $402 \mathrm{~g} / \mathrm{kg} \mathrm{CP}$ and $205 \mathrm{~g} / \mathrm{kg}$ EE (Falahatizow et al., 2015), DHSS could be regarded as a good source of protein and energy.

Because of the high EE content and low neutral detergent fibre level $(160.1 \mathrm{~g} / \mathrm{kg})$, DHSS had high values of AME $(21.0 \mathrm{MJ} / \mathrm{kg})$ and $\mathrm{AME}_{\mathrm{n}}(20.2 \mathrm{MJ} / \mathrm{kg})$. Nadeem et al. (2010) reported values for DHSS of $236.0 \mathrm{~g} / \mathrm{kg} \mathrm{CP}, 329.7 \mathrm{~g} / \mathrm{kg} \mathrm{EE}, 143.0 \mathrm{~g} / \mathrm{kg}$ and CF $35.4 .0 \mathrm{~g} / \mathrm{kg}$, which were lower than the levels observed in the present study. The triple screening and convection performed on DHSS after grinding probably greatly reduced their fibre content (Laudadio et al., 2014). 
Table 4 Nutrient composition of dehulled full-fat sunflower seeds used in experimental diets for broilers

\begin{tabular}{lclc}
\hline Nutritional composition & & \multicolumn{2}{c}{ Essential amino acids, g/16 g of nitrogen } \\
\hline Dry matter, g/kg DM & 935.1 & Methionine & 1.70 \\
Crude protein, g/kg DM & 282.1 & Lysine & 3.16 \\
Ether extract, g/kg DM & 507.9 & Threonine & 3.14 \\
Crude fibre, g/kg DM & 39.9 & Tryptophan & ND \\
Ash, g/kg DM & 47.2 & Arginine & 9.30 \\
Neutral detergent fibre, g/kg DM & 160.1 & Isoleucine & 4.18 \\
Acid detergent fibre, g/kg DM & 143.6 & Leucine & 6.04 \\
Acid detergent lignin, g/kg DM & 97.8 & Valine & 5.00 \\
AME, MJ/kg DM & 21.02 & Histidine & 2.68 \\
AMEn, MJ/kg DM & 20.20 & Phenylalanine & 4.63 \\
& & & \\
\hline
\end{tabular}

DM: dry matter, AME: apparent metabolizable energy, AMEn: apparent metabolizable energy corrected for nitrogen retention

Arginine was the most abundant essential amino acid in DHSS (Table 3). The high content of arginine in DHSS is important since it can reduce pulmonary hypertension in broiler chickens, and is essential for the formation of nitric oxide, which is a potent vasodilator that reduces pulmonary vascular resistance and modulates or inhibits the production and release of vasoconstrictors such as serotonin (Khajali et al., 2011). Rosa et al. (2009) also reported that sunflower meal was high in arginine.

Apparent ileal digestibilities of DM, CP and EE were not significantly different $(P>0.05)$ between the diets (Table 5). Nor did Rodríguez et al. (1998) find significant differences in the AID of EE and CP when DHSS was included in the diet of broiler chickens at $0 \%, 5 \%, 15 \%$ and $25 \%$. These results agree with those of the present experiment (Table 4). However, Fafiolu et al. (2015) reported that the apparent digestibility of DM, CP, EE and CF decreased as SBM was replaced with $0 \%, 25 \%, 50 \%$ and $75 \%$ SFM. These results may be because of the increase in CF content from sunflower meal in the diet. Karkelanov et al. (2020) found an increase in AME when the SFM (20\% of the diet) had low fibre content. Therefore, the de-hulling process is important to reduce the fibre content of DHSS (Senkoylu \& Dale, 2006; Viveros et al., 2009). The high content of dietary CF reduced the transit time of feed in the digestive system, decreasing the digestibility of nutrients (Khajali \& Slominski, 2012).

Table 5 Mean ileal digestibility of dry matter, crude protein and ether extract determined in broilers fed without and with $10 \%$ full-fat de-hulled sunflower seeds in the diet

\begin{tabular}{lcccc}
\hline Nutrient & Control diet & 10\% DHSS diet & SE & $P$-value \\
\hline Dry matter, g.kg DM & 643.0 & 658.0 & 0.13 & 0.585 \\
Crude protein, g/kg DM & 699.0 & 737.0 & 0.14 & 0.195 \\
Ether extract, g/kg DM & 899.0 & 881.0 & 0.08 & 0.301 \\
\hline
\end{tabular}

DHSS: full-fat de-hulled sunflower seeds, DM: dry matter

The inclusion of DHSS significantly affected $(P<0.05)$ only the relative weight of the liver, which increased compared with the control and sorghum-SBM diet (Table 6). The relative weights of crop, proventriculus, gizzard, small intestine and caecum and the relative lengths of the small intestine and caecum were not affected when $10 \%$ DHSS was included in the diet (Table 6). These data were similar to those reported by Salari et al. (2009), who included 7\%, 14\%, and 21\% DHSS in the diet, and found that the relative weights of gizzard and gastrointestinal tract were not affected. However, Rama et al. (2006) reported that total replacement of SBM with SFM increased the relative weights of intestines and gizzard. Moreover, Arija et al. (1998) and Brenes et al. (2008) found that the inclusion of sunflower seeds in the diet increased 
the lengths of small intestine and caecum. This variation could be because of CF differences in the sunflower seed products used in these studies. Rama et al. (2006) found that full replacement of SBM with SFM in the diet $(96.5 \mathrm{~g} / \mathrm{kg} \mathrm{CF}$ ) could cause organ hypertrophy. In the present study, the control diet and the $10 \%$ DHSS diet had 23.9 and $26.4 \mathrm{~g} / \mathrm{kg} \mathrm{CF}$, respectively.

The relative weights of pancreas and spleen did not differ (Table 6$)$ between diets $(P>0.05)$. These results were similar to those found by Brenes et al. (2008), who reported that the inclusion of SFM in the diet did not affect the relative weights of liver, pancreas, and spleen. In the present study (Table 5), the inclusion of $10 \%$ DHSS increased the relative weight of the liver, probably because of hypertrophy caused by polyphenols (Alagawany et al., 2015). On the contrary, Salari et al. (2009) found that the relative weight of the liver decreased significantly in chickens fed full-fat sunflower seed diets compared with the control birds without SFM in the diet. Therefore, further studies are needed to resolve this controversy about the effects of DHSS on chicken organs.

Table 6 Mean relative weights and lengths of intestinal sections and accessory organs determined in broilers fed without and with $10 \%$ full-fat dehulled sunflower seeds in the diet (on fresh basis)

\begin{tabular}{|c|c|c|c|c|}
\hline & Control diet & $10 \%$ DHSS diet & SE & $P$-value \\
\hline \multicolumn{5}{|c|}{ Relative empty weight of main intestinal sections, $\mathrm{g} / \mathrm{kg}$ bodyweight } \\
\hline Crop & 1.59 & 1.89 & 0.09 & 0.08 \\
\hline Proventriculus & 3.20 & 2.96 & 0.12 & 0.33 \\
\hline Gizzard & 10.81 & 9.42 & 0.40 & 0.08 \\
\hline Small intestine & 22.74 & 24.07 & 1.07 & 0.54 \\
\hline Caecum & 2.99 & 7.56 & 1.26 & 0.07 \\
\hline \multicolumn{5}{|c|}{ Relative weight of accessory organs, $\mathrm{g} / \mathrm{kg}$ bodyweight } \\
\hline Liver & 16.37 & 17.90 & 0.31 & 0.01 \\
\hline Pancreas & 1.55 & 1.70 & 0.05 & 0.11 \\
\hline Spleen & 1.26 & 1.04 & 0.07 & 0.11 \\
\hline \multicolumn{5}{|c|}{ Relative length of main intestinal sections, $\mathrm{cm} / \mathrm{kg}$ bodyweight } \\
\hline Small intestine & 58.14 & 55.78 & 1.02 & 0.70 \\
\hline Caeca & 5.67 & 16.05 & 2.81 & 0.06 \\
\hline
\end{tabular}

DHSS: full-fat dehulled sunflower seeds

The $10 \%$ inclusion of DHSS decreased the values of $L^{*}$ and $b^{*}(P<0.05)$ of the breast, but not $\mathrm{a}^{*}(P$ $>0.05$ ) (Table 7). When chickens were fed the DHSS diet, the $L^{*}$ and $b^{*}$ colour parameters of the breast skin decreased (Table 7 ). That is, the skin became 3.5\% darker and $13.8 \%$ less yellow (Weatherall \& Coombs, 1992). Alagawany et al. (2015) showed that products made with sunflower seeds tended to darken, owing to the presence of polyphenolic compounds, mainly chlorogenic acid, physiological functions of which on meat colour may be attributed to their antioxidant properties, delaying myoglobin and haemoglobin oxidation in meat (Zhao et al., 2019).

Table 7 Means of breast colour values determined in broilers fed without and with $10 \%$ full-fat dehulled sunflower seeds, in the diet

\begin{tabular}{lrrrr}
\hline Colour value & Control diet & $10 \%$ DHSS diet & SE & $P$-value \\
\hline $\mathrm{L}^{*}$ & $51.60^{\mathrm{a}}$ & $49.80^{\mathrm{b}}$ & 0.40 & 0.03 \\
$\mathrm{a}^{*}$ & $9.40^{\mathrm{a}}$ & $10.40^{\mathrm{a}}$ & 0.27 & 0.06 \\
$\mathrm{~b}^{*}$ & $10.90^{\mathrm{a}}$ & $9.40^{\mathrm{b}}$ & 0.31 & 0.02
\end{tabular}

DHSS: full-fat dehulled sunflower seeds, $L^{*}$ : lightness, $a^{*}$ : redness, $b^{*}$ : yellowness

${ }^{a, b}$ Means in the same row with a common superscript were not different with probability $P<0.05$ 
The inclusion of DHSS did not affect $(P>0.05)$ growth, feed consumption or FCR (Table 8). These values differed from those reported by Arija et al. (1999), who found that the inclusion of $5 \%, 10 \%$ and $15 \%$ DHSS in broiler diets at 28 days old decreased FI and live weight gain (LWG), without affecting FCR. However, Selvaraj \& Purushothaman (2004) reported that FCR improved when sunflower seeds were added ( $0 \%$ to $20 \%$ ) to broiler diets. Salari et al. (2009) observed that the inclusion of $7 \%, 14 \%$ and $21 \%$ DHSS in starter and finisher diets improved LWG, FI, and FCR compared with the control diet. This disagreement may be explained by the variation in chemical composition of the sunflower seeds. In this experiment, a low level of DHSS (10\%) was used, since high values of EE $(507.9 \mathrm{~g} / \mathrm{kg})$ and AMEn $(20.20 \mathrm{MJ} / \mathrm{kg})$ could limit the FI of the chickens.

Table 7 Means of cumulative productive variables as determined for 33 to 54 day old broilers fed without and with $10 \%$ full-fat dehulled sunflower seeds in the diet

\begin{tabular}{lrrrr}
\hline Cumulative productive variables & Control diet & $10 \%$ DHSS diet & SE & $P$-value \\
\hline Final weight, g/chicken & 3478.70 & 3502.50 & 35.96 & 0.73 \\
Weight gain, g/chicken & 1818.20 & 1772.40 & 25.44 & 0.39 \\
Feed intake, g/chicken & 3729.00 & 3866.90 & 54.76 & 0.22 \\
Feed conversion ratio, g/g & 2.05 & 2.10 & 0.04 & 0.07 \\
\hline
\end{tabular}

DHSS: full-fat dehulled sunflower seeds

\section{Conclusions}

The partial replacement of SBM with 10\% DHSS in broiler finisher diets did not affect the size of digestive organs, ileal digestibility, growth and feed consumption. Only slight changes were observed in breast colour parameters and relative liver weight. Therefore, DHSS was deemed a good source of protein, energy and arginine for broiler chickens.

\section{Acknowledgements}

UMM thanks the Consejo Nacional de Ciencia y Tecnología (CONACyT) for the scholarship to carry out master's studies at Colegio de Postgraduados, Mexico.

\section{Authors' Contributions}

FGC and APM conceived and designed the experiments. UMM performed the experiments and received his MSc degree. LTRO and JGS analysed the data. ESM and APM contributed reagents and materials. APM, ESM and UMM wrote the paper. APM, ESM and FGC edited the manuscript.

\section{Conflict of Interest Declaration}

The authors declare there is no conflict of interest.

\section{References}

Alagawany, M., Farag, M.R., El-Hack, M.E.A. \& Dhama, K., 2015. The practical application of sunflower meal in poultry nutrition. Adv. Anim. Vet. Sci. 3, 634-648. http://dx.doi.org/10.14737/journal.aavs/2015/3.12.634.648

Arija, I., Brenes, A., Viveros, A. \& Elices, R., 1998. Effects of inclusion of full-fat sunflower kernels and hulls in diets for growing broiler chickens. Anim. Feed Sci. Technol. 70, 137-149. https://doi.org/10.1016/S0377-8401(97)00077-1

Arija, I., Canales, R., Brenes, A. \& Montoro, A.V., 1999. Estudio del valor nutritivo de la semilla de girasol entera descascarillada en raciones de pollos broiler y su efecto sobre la concentración de ácidos grasos en la grasa abdominal. Arch. Zootec. 48(183), 249-259.

Association of Official Analytical Chemists (AOAC), 1990. Official methods of analysis. 15th ed. AOAC, Washington DC, USA.

Aviagen, 2017. Pollo de engorde Ross 308. Especificaciones de Nutrición Aviagen Ltd, Newbridge, UK. http://es.aviagen.com/

Barzegar, S., Wu S., Noblet, J. \& Swick, R.A., 2019. Metabolizable energy of corn, soybean meal and wheat for laying hens. Poult. Sci. 98(11), 5876-5882. http://dx.doi.org/10.3382/ps/pez333

Bertechini, A.G., Kato, R.K., Villas-Bôas de Freitas, L.F., da Costa Castro, R.T. \& Mazzuco, H, 2019. Metabolizable energy values of soybean meals and soybean oil for broilers at different ages. Acta Scientiarum. Anim. Sci. 41, e44540. https://doi.org/10.4025/actascianimsci.v41i1.44540

Brenes, A., Centeno, C., Viveros, A. \& Arija, I., 2008. Effect of enzyme addition on the nutritive value of high oleic acid sunflower seeds in chicken diets. Poult. Sci. 87, 2300-2310. https://doi.org/10.3382/ps.2008-00130 
Fafiolu, A.O., Oduguwa, O.O., Jegede, A.V., Tukura, C.C., Olarotimi, I.D., Teniola, A.A. \& Alabi, J.O., 2015. Assessment of enzyme supplementation on growth performance and apparent nutrient digestibility in diets containing undecorticated sunflower seed meal in layer chicks. Poult. Sci. 94, 1917-1922. https://doi.org/10.3382/ps/pev136

Falahatizow, J., Danesh Mesgaran, M., Vakili, A.R., Tahmasbi, A.M. \& Nazari, M.R., 2015. The estimation of ruminal protein degradation parameters of various feeds using in vitro modified gas production technique. Iranian J. Vet. Res. 16(1), 47-52.

Huerta-Paniagua, R.A., Bautista-Martínez, N., Bravo-Mojica, H., Carrillo-Sánchez, J.L. \& Díaz-Gómez, O., 2004. Altitude distribution of Trichobaris championi Barber (Coleoptera: Curculionidae) and field observations about its biology. Agrociencia 38(1), 97-106.

Karkelanov, N., Chobanova, S., Dimitrova, K., Whiting, I.M., Rose, S.P. \& Pirgozliev. V., 2020. Feeding value of dehulled sunflower seed meal for broilers. Acta Agroph. 27, 31-38. https://doi.org/10.31545/aagr/126566

Kaya, Y., 2020. Sunflower production in Black Sea region: The situation and problems. International Journal of Innovative Approaches in Agricultural Research 4(1), 147-155. DOI: 10.29329/ijiaar.2020.238.15

Khajali, F., Tahmasebi, M., Hassanpour, H., Akbari, M.R., Qujeq, D. \& Wideman, R.F., 2011. Effects of supplementation of canola meal-based diets with arginine on performance, plasma nitric oxide, and carcass characteristics of broiler chickens grown at high altitude. Poult. Sci. 90, 2287-2294. https://doi.org/10.3382/ps.2011-01618

Khajali, F. \& Slominski, B.A., 2012. Factors that affect the nutritive value of canola meal for poultry. Poult. Sci. 91, 25642575. https://doi.org/10.3382/ps.2012-02332

Khempaka, S., Molee, W. \& Guillaume, M., 2009. Dried cassava pulp as an alternative feedstuff for broilers: Effect on growth performance, carcass traits, digestive organs, and nutrient digestibility. Journal of Applied Poultry Research 18 (3), 487-493. https://doi.org/10.3382/japr.2008-00124

Konyali, S., 2017. Sunflower production, consumption, foreign trade and agricultural policies in Turkey. Social Sciences Res. J. 6(4), 11-19. https://www.researchgate.net/publication/333079533

Laudadio, V., Ceci, E., Lastella, N.M.B. \& Tufarelli, V., 2014. Effect of feeding low-fiber fraction of air-classified sunflower (Helianthus annus L.) meal on laying hen productive performance and egg yolk cholesterol. Poult. Sci. 93, 28642869. https://doi.org/10.3382/ps.2014-04204

Morales-Rosales, E.J., Escalante-Estrada, J.A., Tijerina-Chávez, L., Volke-Haller, V. \& Sosa-Montes, E., 2006. Biomasa, rendimiento, eficiencia en el uso del agua y de la radiación solar del agrosistema girasol-frijol. Terra Latinoamericana 24(1), 55-64.

Myers, W.D., Ludden, P.A., Nayigihugu, V. \& Hess, B.W., 2004. Technical note: a procedure for the preparation and quantitative analysis of samples for titanium dioxide. J. Anim. Sci. 82, 179-183. https://doi.org/10.2527/2004.821179x

Nadeem, M., Anjum, F.M., Arshad, M.U. \& Hussain, S., 2010. Chemical characteristics and antioxidant activity of different sunflower hybrids and their utilization in bread. Afr. J. Food Sci. 4(10), 618-626. https://academicjournals.org/journal/AJFS/article-abstract/A91483D26048

Norma Oficial Mexicana, 2015. NOM-033-SAG/ZOO-2014. Métodos para dar muerte a los animales domésticos y silvestres. 26 de agosto de 2015. Diario Oficial de la Federación, México.

Rama Rao, S.V., Raju, M.V.L.N., Panda, A.K. \& Reddy, M.R., 2006. Sunflower seed meal as a substitute for soybean meal in commercial broiler chicken diets. Br. Poult. Sci. 47, 592-598. https://doi.org/10.1080/00071660600963511

Rodríguez, M., Ortiz, L., Treviño, J., Rebolé, A., Alzueta, C. \& Centeno, C., 1998. Studies on the nutritive value of full-fat sunflower seed in broiler chick diets. Anim. Feed Sci. Technol. 71, 341-349. https://doi.org/10.1016/S03778401(97)00151-X

Rosa, P.M., Antoniassi, R., Freitas, S.C., Bizzo, H.R. Zanotto, D. L., Oliveira, M.F. \& Castiglioni, V.B.R., 2009. Chemical composition of Brazilian sunflower varieties. Helia 32 (50), 145-156. https://doi.org/10.2298/hel0950145r

Salari, S., Moghaddam, H.N., Arshami, J. \& Golian, A., 2009. Nutritional evaluation of full-fat sunflower seed for broiler chickens. Asian-Australas. J. Anim. Sci. 22, 557-564. https://doi.org/10.5713/ajas.2009.80481

Selvaraj, R.K. \& Purushothaman, M.R., 2004. Nutritive value of full-fat sunflower seeds in broiler diets. Poult. Sci. 83(3), 441-446. https://doi.org/10.1093/ps/83.3.441

Senkoylu, N. \& Dale, N., 2006. Nutritional evaluation of a high-oil sunflower meal in broiler starter diets. J. Appl. Poult. Res. 15, 40-47. https://doi.org/10.1093/japr/15.1.40

Tsuzuki, E., Garcia, E. de M., Murakami, A., Sakamoto, M. \& Galli, J., 2003. Utilization of sunflower seed in laying hen rations. Rev. Bras. Ciênc. Avícola 5, 179-182. https://doi.org/10.1590/S1516-635X2003000300004

Van Soest, P.J., Robertson, J.B. \& Lewis, B.A., 1991. Methods for dietary fiber, neutral detergent fiber, and nonstarch polysaccharides in relation to animal nutrition. J. Dairy Sci. 74, 3583-3597. https://doi.org/10.3168/jds.S00220302(91)78551-2

Viveros, A., Ortiz, L.T., Rodríguez, M.L., Rebolé, A., Alzueta, C., Arija, I., Centeno, C. \& Brenes, A., 2009. Interaction of dietary high-oleic-acid sunflower hulls and different fat sources in broiler chickens. Poult. Sci. 88, 141-151. https://doi.org/10.3382/ps.2008-00226

Weatherall, I.L., \& Coombs, B.D., 1992. Skin color measurements in terms of CIELAB color space values. J. Invest. Dermatol. 99(4), 468-473. https://pubmed.ncbi.nlm.nih.gov/1402005/

Zając, M., Kiczorowska, B., Samolińska, W. \& Klebaniuk, R., 2020. Inclusion of camelina, flax, and sunflower seeds in the diets for broiler chickens: apparent digestibility of nutrients, growth performance, health status, and carcass and meat quality traits. Animals 10(2), 321. https://doi.org/10.3390/ani10020321

Zhao, J.S., Deng, W. \& Liu H.W., 2019. Effects of chlorogenic acid-enriched extract from Eucommia ulmoides leaf on performance, meat quality, oxidative stability, and fatty acid profile of meat in heat-stressed broilers. Poult. Sci. 98, 3040-3049. http://dx.doi.org/10.3382/ps/pez081 